\title{
Should climate change make us think more about the economics of forest management?
}

\author{
by Jing Yang ${ }^{1}$, Daniel W. McKenney² and Alfons Weersink ${ }^{3}$
}

\begin{abstract}
Forest management agencies have budget constraints and continually face difficult questions regarding how much to invest in silviculture and when to harvest forests. Economic thought suggests these decisions should be guided by the pursuit of economic efficiency and tools like net present value (NPV) analysis. In forestry this would make use of the so-called Faustmann model and generally result in shorter rotation ages than the Maximum Sustained Yield (MSY) criterion, which is often used as a policy objective in forest management. The two approaches have caused tension and controversy between foresters and economists. Climate change is adding yet another uncertainty dimension to the forest management challenge. Global climate models suggest massive changes in climate this coming century that will surely affect forests. Here we use climate change as a backdrop to compare the MSY and Faustmann results for black spruce (Picea mariana) and white pine (Pinus strobus) in Ontario. Climate change is adding new risks to silvicultural investments. Our intent is not to "resolve" the management problem but highlight some issues and differences between the two approaches. We suggest that climate change could, or should, cause a resurgence of the debate over pursuit of intertemporal efficiency in forest management.
\end{abstract}

Keywords: forest economics, climate change, uncertainty, black spruce, white pine

\section{RÉSUMÉ}

Les agences d’aménagement forestier subissent des contraintes budgétaires et font face continuellement à d'épineuses questions à savoir combien investir en sylviculture et quand exploiter les forêts. L'école de pensée économique suggère que les décisions devraient être guidées par la recherche de l'efficience économique et par des outils comme l'analyse de la valeur actuelle nette (VAN). En foresterie, cela signifierait l'utilisation du modèle dit de Faustmann et entraînerait généralement des révolutions plus courtes que celles générées par le critère de rendement maximal soutenu (RMS), qui est souvent utilisé comme objectif politique en aménagement forestier. Les deux approches ont provoqué des tensions et des controverses entre les forestiers et les économistes. Les changements climatiques ajoutent une autre dimension d'incertitude au défi de laménagement forestier. Les modèles climatiques mondiaux laissent entrevoir des changements climatiques importants au cours du présent siècle qui auront surement un impact sur les forêts. Nous utilisons ici les changements climatiques comme toile de fonds pour comparer les résultats tirés du RMS et du modèle Faustmann dans le cas dépinette noire (Picea mariana) et du pin blanc (Pinus strobus) en Ontario. Les changements climatiques ajoutent de nouveaux risques au niveau des investissements sylvicoles. Notre objectif nest pas de « résoudre » cette problématique d’aménagement mais de souligner certaines questions et différences entre les deux approches. Nous suggérons que les changements climatiques pourraient, ou devraient entraîner une résurgence du débat sur la poursuite de l'efficacité intemporelle de laménagement forestier.

Mots clés : économie forestière, changements climatiques, incertitude, épinette noire, pin blanc

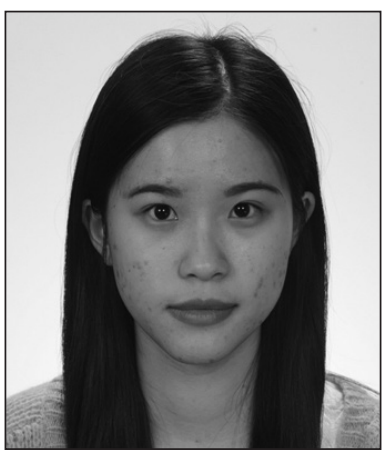

Jing Yang

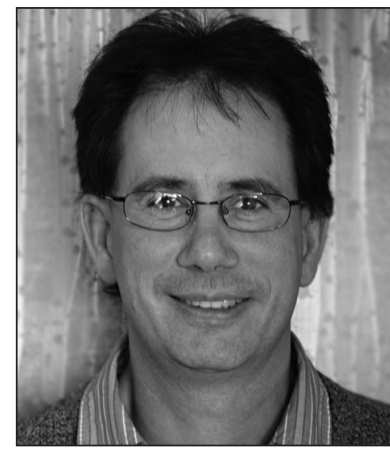

Daniel W. McKenney

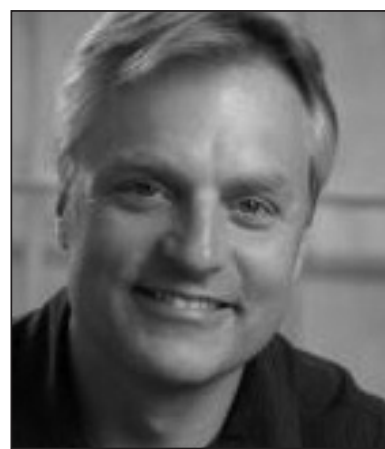

Alfons Weersink

\section{Introduction}

There is significant concern over the possible impacts of rapid climate change on forest systems (IPCC 2007, 2013). For example, in the productive forest zones of Ontario the average annual temperature could increase $4.2^{\circ} \mathrm{C}$ and annual precipitation could increase 30\% by 2100 (Price et al. 2013, McKenney et al. 2009). Assessments of climate change

\footnotetext{
${ }^{1}$ Graduate Student, Food, Agricultural and Resource Economics, University of Guelph, Guelph, Ontario N1G 2 W1.

${ }^{2}$ Chief, Landscape Analysis and Applications, Canadian Forest Service, Great Lakes Forestry Centre, Sault Ste. Marie, Ontario P6A 2 E5.

${ }^{3}$ Professor, Food, Agricultural and Resource Economics, University of Guelph, Ontario N1G 2W1.

*Corresponding author. E-mail: Dan.McKenney@nrcan.gc.ca
} 
impacts on forests and adaptation options for forestry are the subject of much scientific research (Aitken et al. 2008, Seidl et al. 2011, Lemprière et al. 2013, Williams and Dumroese 2013). If future climate change proceeds as projected, it will cause tremendous pressure on species to migrate, affect growth, mortality, succession, and change disturbance regimes such as fire and insect outbreaks across large landscapes (Campbell et al. 2009, Boulanger et al. 2013, Price et al. 2013, Park et al. 2014).

It is an understatement to note that translating these possible impacts into changes in current forest management planning and decisions is highly challenging (Pedlar et al. 2012: Pedlar J.H., McKenney D.W., Aubin I., Beardmore T., Beaulieu J., Iverson L., O’Neill G.A., Winder R.S., and Ste-Marie C. 2012. Placing forestry in the assisted migration debate. BioScience 62:835-842.). The subject offers another opportunity to highlight some of the differences between the traditional forestry paradigm of Maximized Sustained Yield (MSY) and a more economic approach to investment and rotation decisions in forest management (Samuelson 1976; Newman 1988, 2002). Indeed, this debate between foresters and economists is known to long-time readers of The Forestry Chronicle (e.g., Pearse 1967, Walker 1990, McKenney 2000, Luckert 2002). MSY implies a balance between growth and harvest potentials with the harvest at an age where average annual growth of timber volume is maximized, resulting in the largest harvest level that does not deplete the future timber resource (Walker 1990, Luckert and Williamson 2005). However, the MSY approach generally does not consider the value of the standing timber or management costs. Thus, the MSY approach ignores the implications of economic efficiency for management decisions (Samuelson 1976, Newman 1988). An economic approach to forest management has its roots in the work of Martin Faustmann (1849), the German forester credited with being the father of modern discounted cash flow analysis (see Newman 2002). In contrast to MSY, a Faustmann-type approach explicitly considers silviculture costs and an economic interpretation of the value of the standing timber to society relative to the cost of obtaining the timber.

Here we compare Faustmann versus MSY rotation ages and values for two important Ontario tree species, black spruce (Picea mariana (Mill.) BSP) and eastern white pine (Pinus strobus L.), and show some simple conceptions of climate change impacts. The comparison provides a more practical look at some of the trade-offs involved in these two decision criteria and the influence of climate change on those trade-offs. What we hope arises from this discussion is an increased dialogue on the idea of economic efficiency versus the MSY doctrine in the face of what many would argue is one of the most pressing challenges of modern forestry--adapting to a changing climate.

\section{Optimal Economic Rotation Approach vs. MSY}

Applications of both MSY and the Faustmann approaches require information on the empirical form of a growth function $(V(t))$, production data on the relationship between tree age $(t)$ and tree volume $(V)$ in order to estimate the growth function. The Faustmann model also needs estimates of the standing timber value which, in some contexts, is the (net of harvest cost) stumpage price $(P)$, the regeneration/establishment cost $(C)$, and the time cost of the capital investment (the discount rate, $r$ ). One of the main sources of discontent between foresters and economists appears to be whether regeneration costs should be considered as a cost applied to the "next" generation stand and hence affect rotation ages and wood flows. The economic approach (well-articulated by the Nobel prize-winning economist Paul Samuelson, 1976) argues that an economic framework helps assess the trade-offs among choices in regeneration.

For a given investment, discount rate and standing timber value, the basic Faustmann model identifies the optimal rotation age as the harvest period at which the net present value of a forest stand over an infinite series of (physically sustainable) rotations is maximized. At the end of each rotation, the same net revenue $(P V(t))$ is received from the harvest and an establishment cost of $C$ is again incurred to plant the next stand. Mathematically, the present value of net returns (NPV) received from an infinite series of rotations can be expressed as

[1]

$$
\begin{aligned}
\mathrm{NPV} & =(P V(t)-C) e^{-r t}\left(1+e^{-2 r t}+e^{-3 r t}+\ldots\right)-C \\
& =\frac{(P V(t)-C) e^{-r t}}{\left(1-e^{-r t}\right)}-C \\
& =\frac{(P V(t)-C)}{\left(e^{t}-1\right)}-C
\end{aligned}
$$

where NPV is the present value of net returns received on a \$/ ha basis when harvesting occurs at age $r t$, and is the discount factor, $P V(t)$ the net revenue received from the harvest and $C$ the establishment cost. The rotation age that maximizes NPV can be found by taking the first derivative of [1]. When the marginal gain/benefit of increasing the harvest one more period is greater than the marginal cost of doing so, the harvest should be delayed--otherwise harvest the stand (Conrad 1999). The intuition is clear but application does require judgment and debate about future values. Ultimately, the Faustmann condition implies that the stand remains uncut until the rate of asset growth is equal to the adjusted interest rate or time preference rate. The cost of time is a critical consideration for any analysis of natural resource use (see Portney and Weyant 1999). Row et al. (1981), Kula (1984), Boardman et al. (2010) and Moore et al. (2013) suggest a real long-run rate of time preference in the neighborhood of $3 \%$ to $5 \%$.

A comparative static analysis (i.e., comparing the two different outcomes before and after a change in exogenous factors with all else being the same) indicates how small (marginal) changes in variables affect the optimal rotation period (in this case $P, C, r$ and $V$ ). The comparative static results are derived by setting the first derivative of the Faustmann model given by [1] to zero and solving for the rotation age $t$. This kind of mathematical analysis (Chang 1984, Conrad 1999) shows that an increase in the stumpage price reduces the optimal rotation period. Conversely, an increase in establishment costs lengthens the rotation period while an increase in the discount rate lowers the rotation period. Finally, an increase in tree volume shortens the rotation age.

The MSY approach maximizes the average annual physical yield from a stand $(V(t) / t)$. The rotation age that maximizes MSY is when the marginal increase in yield () is equal to the average yield of the stand $(V(t) / t)$ 


$$
\text { [2] } \quad V(t)^{\prime}=\frac{V(t)}{t}
$$

In contrast to a Faustmann approach, MSY policy is focused solely on tree volume and is not sensitive to changes in costs or end product values. MSY almost always (Binkley 1987) results in a longer rotation than suggested under the Faustmann rule and hence produces more volume of wood at the harvest age. There is an argument that longer rotations provide more non-wood benefits (e.g., a wider range of age classes to support wildlife or other aspects of biodiversity) (Luckert and Williamson 2004). As noted above, this issue has been addressed in a modified Faustmann-type model (Hartman 1976, Nguyen, 1979), with the important outcome being that once non-wood values are formally brought into an analysis, the optimal rotation may be longer or shorter than either Faustmann or MSY rotations (see also Bowes and Krutilla 1989). The inclusion of such values may even suggest no harvesting is the appropriate economic policy; the details/circumstances of the particular forest management problem will drive the result. Notably, the Ontario Ministry of Natural Resources has recently adopted a policy to more explicitly consider the economics of non-wood values in forest management (OMNR 2014). What this means in practice remains to be seen.

Given our intent is simply to illustrate some of the more stark trade-offs between the Faustmann and MSY models, we have implemented only the basic, wood-only Faustmann stand-level model in an Ontario context. We report rotation age, NPV and harvest volume differences between the approaches. They should serve as important metrics for forest managers who may be interested in these kinds of policy debates. Application to specific forest-wide problems is doable using tools such as linear programming (Johansson and Lofgren 1985) but is not needed for our purposes.

\section{Data}

A growth function (or yield table) is necessary for both the Faustmann and MSY decision criteria. Here we used yield tables generated by Plonski $(1956,1960)$ that have been widely used in Ontario (Payandeh 1991). We recognize there is ongoing work on growth and yield in Ontario (e.g., Sharma et al. 2008) but the Plonski data easily serve our purpose. Growth and yield expectations under a changing climate are still a matter of much scientific investigation. Researchers employ methods ranging from estimating statistical relationships between climate variables and yields (e.g., Ung et al. 2009) to mechanistic or biological process approaches (e.g., Girardin et al. 2008). Coulombe et al. (2010) predict future mean merchantable volume of black spruce will be $30 \%$ greater than under current climate. However, Girardin et al. (2008) suggest that a continuously warming climate accounts, in large part, for a decrease in forest productivity. Other modeling efforts raise questions about possible large changes in the growing habitats of Canadian tree species during the coming century, given projected climate change. For example, McKenney et al. $(2007,2011 \mathrm{a})$ suggest that the core climate habitat of some 130 tree species could move north by over $700 \mathrm{~km}$ by the later part of this century. Clearly there could be many depictions and debates on the possible effects of a changing climate on a forest stand's growth and yield. For illustration purposes here, we assume that the gross merchantable tree volume would range from $30 \%$ greater to $30 \%$ less than current expectations. This is roughly based on Coulombe et al. (2010) and Girardin et al. (2008). Again, we need to note that our intent is not to resolve this problem but investigate the implications of some different beliefs. Modeling frameworks like those here can be used to explicitly represent many beliefs.

Regeneration costs, or establishment costs $(C)$, are incurred after a stand is harvested (or implicitly before it is harvested) and may include expenses such as site preparation, seeding, planting, planting with genetically improved stock, and vegetation control. To represent the continuum of extensive to intensive silviculture options and the inherent uncertainty in analyses such as these, we portray costs ranging from $\$ 100 /$ ha to $\$ 1200 /$ ha. We assume real stumpage values $(P)$ ranging from $\$ 10 / \mathrm{m}^{3}$ to $\$ 50 / \mathrm{m}^{3}$ (representing low- to higher-value future prices), and allow the discount rate $(r)$ to range from $4 \%$ to $8 \%$ (again representing low to higher time preference rates). For the sake of simplicity, we assume that the growth and yield function does not change with different investment levels. To help with some of the comparisons, we have chosen a baseline scenario, with the stumpage price/value assumed to be $\$ 20 / \mathrm{m}^{3}$, establishment cost of $\$ 300 /$ ha and the discount rate of $4 \%$. Also note that we assume that minimum merchantable volumes would be $80 \mathrm{~m}^{3} /$ ha, i.e., a stand would have to contain at least $80 \mathrm{~m}^{3}$ before it would be considered merchantable or potentially harvestable. Of course, transport distance would have an influence on a firm's willingness to pay to harvest a stand but our intent here is to investigate the trade-off between stand level investments and returns on those investments.

\section{Results}

\section{Base case - Faustmann vs. MSY}

Based on our estimated yield function, the harvest age and corresponding volume and NPV for both the MSY and Faustmann approaches are listed in Table 1. For the base case, the optimal rotation age on site class 1 land occurs at 56 years for black spruce, which is about half the harvest age under the MSY rule ( 59 years shorter). Harvest volumes between the two rules are $93 \mathrm{~m}^{3} / \mathrm{ha}$ (Faustmann) versus $266 \mathrm{~m}^{3} / \mathrm{ha}$ (MSY). While the optimal harvest age increases on lower-quality land for both the Faustmann and MSY criteria, the extent of the increase is not as great using NPV as the guiding metric. The optimal rotation length is 94 years on site class 3 using the Faustmann formula, whereas the mathematical function suggests it would be 276 years with MSY (this is well beyond the data in the Plonski table and hence likely unreliable--the take-home point being the MSY rotation age is, as one might expect, much longer than the basic Faustmann model would suggest).

The harvest age for white pine is 40 years with the Faustmann rule versus 71 years with the MSY rule on site class 1 . On site class 3 , the optimal rotation length increases to 61 years using the economic criterion versus 134 years with the MSY rule. The net returns for white pine harvesting at the optimal Faustmann age are $\$ 466 /$ ha on site class 1 and $-\$ 187 /$ ha for site class 3 (as compared to $\$ 137 / \mathrm{ha}$ and $-\$ 277 / \mathrm{ha}$ for MSY).

Generally, returns for white pine are substantially higher than for black spruce. Returns to black spruce are negative for all three site classes and the loss increases as the site class declines. 
Table 1. Climate change effects on optimal rotation age and corresponding net present value and harvest volume with Faustmann formula and Maximized Sustained Yield (MSY) criteria for black spruce and white pine in Ontario

\begin{tabular}{|c|c|c|c|c|c|c|c|c|}
\hline \multirow[b]{2}{*}{ Climate scenario } & \multirow[b]{2}{*}{ Species } & \multirow[b]{2}{*}{ Site class } & \multicolumn{3}{|c|}{ Faustmann rule } & \multicolumn{3}{|c|}{ MSY } \\
\hline & & & $\begin{array}{c}\text { Age } \\
(\mathbf{t})\end{array}$ & $\begin{array}{l}\text { Profit } \\
\text { (\$/ha) }\end{array}$ & $\begin{array}{l}\text { Volume } \\
\left(\mathrm{m}^{3} / \mathrm{ha}\right)\end{array}$ & $\begin{array}{l}\text { Age } \\
(\mathbf{t})\end{array}$ & $\begin{array}{l}\text { Profit } \\
\text { (\$/ha) }\end{array}$ & $\begin{array}{l}\text { Volume } \\
\left(\mathrm{m}^{3} / \mathrm{ha}\right)\end{array}$ \\
\hline \multirow[t]{9}{*}{ No change } & black & 1 & 56 & -106 & 93 & 115 & -244 & 266 \\
\hline & spruce & 2 & 81 & n.a & 78 & 216 & -298 & 409 \\
\hline & & & 82 & -245 & $80^{\mathrm{a}}$ & & & \\
\hline & & 3 & 99 & n.a & 63 & 276 & -300 & 379 \\
\hline & & & 108 & -281 & $80^{a}$ & & & \\
\hline & white pine & 1 & 40 & 466 & 160 & 71 & 137 & 347 \\
\hline & & 2 & 47 & 86 & 164 & 89 & -129 & 287 \\
\hline & & 3 & 63 & n.a & 76 & 134 & -277 & 233 \\
\hline & & & 65 & -187 & $80^{a}$ & & & \\
\hline \multirow[t]{7}{*}{$30 \%$ more } & black & 1 & 55 & -36 & 116 & 115 & -227 & 345 \\
\hline & spruce & 2 & 79 & -225 & 95 & 216 & -298 & 532 \\
\hline & & 3 & 94 & n.a & 71 & 276 & -300 & 492 \\
\hline & & & 98 & -279 & $80^{\mathrm{a}}$ & & & \\
\hline & & 1 & 40 & 720 & 209 & 71 & 274 & 451 \\
\hline & & 2 & 46 & 219 & 147 & 89 & -75 & 373 \\
\hline & & 3 & 61 & -144 & 92 & 134 & -270 & 303 \\
\hline \multirow[t]{10}{*}{$30 \%$ less } & black & 1 & 58 & n.a & 70 & 115 & -262 & 186 \\
\hline & spruce & & 64 & -178 & $80^{a}$ & & & \\
\hline & & 2 & 84 & n.a & 60 & 216 & -299 & 287 \\
\hline & & & 95 & -268 & $80^{a}$ & & & \\
\hline & & 3 & 101 & n.a & 47 & 276 & -300 & 265 \\
\hline & & & 126 & -291 & $80^{*}$ & & & \\
\hline & white pine & 1 & 41 & 212 & 117 & 71 & 137 & 347 \\
\hline & & 2 & 49 & -46 & 89 & 89 & -129 & 287 \\
\hline & & 3 & 66 & n.a. & 59 & 134 & -277 & 233 \\
\hline & & & 79 & -237 & $80^{\mathrm{a}}$ & & & \\
\hline
\end{tabular}

a To reflect a merchantability constraint a stand volume of at least $80 \mathrm{~m}^{3} /$ ha is required for harvesting to be allowed; see text for details.

Note: Climate change effect on tree growth is manifested by plus and minus $30 \%$ changes in tree volume. The price in this initial analysis is set at $\$ 20 / \mathrm{m}^{3}$, cost is set at $\$ 300 /$ ha and discount rate is $4 \%$; Sites 1 (3) are the best (worst) quality land.

For this level of investment and stumpage value, white pine has positive net returns on site classes 1 and 2 but not site class 3 . The current study generally reiterates the findings of Insley et al. (2002) and Rollins et al. (1995). The magnitude of the differences in net returns within and between white pine and black spruce should raise questions to forest managers about investment levels and benefits of silvicultural options for both species.

In contrast to the Faustmann formula, whose results are driven by a combination of factors aimed at maximizing net economic benefits through time, MSY is aimed at maximizing mean annual growth. On site class 1 , forest managers gain an additional $138 \mathrm{~m}^{3} /$ ha for black spruce and $187 \mathrm{~m}^{3} / \mathrm{ha}$ for white pine using MSY policy. The substantial loss in value is largely driven by the effect of discounting. Deviating from this rule implies a transfer of income/wealth from the investor (land owner- the Crown in much of the forests of Canada) to those who benefit from this rule. For site class 1, choosing MSY management results in a NPV that is $\$ 138 /$ ha less for black spruce and $\$ 329 /$ ha less for white pine than the
Faustmann approach. When multiplied across large landscapes total losses would accumulate.

\section{Price, cost and discount rate change effects}

NPVs and rotation lengths under alternative assumptions in establishment cost, stumpage value, and discount rate are given in Table 2 for both black spruce and white pine for site class 1 land. Note again that the MSY rotation length would not change if any of these factors change. Changes in NPV values are particularly striking across the stumpage prices, establishment costs and discount rates. Rotation lengths arguably do not change quite as significantly but are still notable. Price increases act to decrease rotation length across both species. NPV increases with stumpage price increases and decreases in establishment costs and discount rate. Conversely, NPV decreases with stumpage price decreases and increases in establishment costs and the discount rate. These effects are as would be expected, given the comparative statics analysis discussed previously. However, actual numerical results should be examined and debated if economic efficiency is viewed 
Table 2. Net present value (and optimal rotation age) for black spruce and white pine on site class 1 land for alternative establishment costs, stumpage price and discount rate for two assumed climate change growth rate effects

\begin{tabular}{|c|c|c|c|c|c|c|}
\hline \multirow[b]{2}{*}{ Species } & \multirow[b]{2}{*}{$\begin{array}{l}\text { Establishment } \\
\text { cost }(\$)\end{array}$} & \multirow[b]{2}{*}{$\begin{array}{c}\text { Stumpage price } \\
\left(\$ / \mathbf{m}^{3}\right)\end{array}$} & \multirow[b]{2}{*}{ Discount rate } & \multicolumn{3}{|c|}{ Climate scenario } \\
\hline & & & & No change & $\begin{array}{l}30 \% \text { more } \\
\text { volume }\end{array}$ & $\begin{array}{c}30 \% \\
\text { less volume }\end{array}$ \\
\hline \multirow[t]{12}{*}{ Black spruce } & 100 & 10 & $4 \%$ & $4(55)^{\mathrm{a}}$ & $39(54)$ & $-31(56)^{d}$ \\
\hline & & & $8 \%$ & $-85(43)^{\mathrm{b}}$ & $-79(42)^{\mathrm{c}}$ & $-91(45)^{\mathrm{d}}$ \\
\hline & & 50 & $4 \%$ & $477(52)^{\mathrm{b}}$ & $655(51)$ & $299(52)^{d}$ \\
\hline & & & $8 \%$ & $-6(39)^{b}$ & $24(39)^{\mathrm{c}}$ & $-36(40)^{\mathrm{d}}$ \\
\hline & 400 & 10 & $4 \%$ & $-329(64)$ & $-297(61)$ & $-360(69)$ \\
\hline & & & $8 \%$ & $-393(54)$ & $-388(51)$ & $-397(59)^{d}$ \\
\hline & & 50 & $4 \%$ & $133(54)$ & $309(53)$ & $-44(55)^{\mathrm{d}}$ \\
\hline & & & $8 \%$ & $-320(42)^{b}$ & $-291(41)^{c}$ & $-349(44)^{\mathrm{d}}$ \\
\hline & 1200 & 10 & $4 \%$ & $-1175(87)$ & $-1153(79)$ & $-1192(103)$ \\
\hline & & & $8 \%$ & $-1199(77)$ & $-1197(69)$ & $-1200(93)$ \\
\hline & & 50 & $4 \%$ & $-767(59)$ & $-596(57)$ & $-934(62)^{\mathrm{d}}$ \\
\hline & & & $8 \%$ & $-1147(48)^{\mathrm{b}}$ & $-1121(46)^{c}$ & $-1171(52)^{\mathrm{c}}$ \\
\hline \multirow[t]{12}{*}{ White pine } & 100 & 10 & $4 \%$ & 297(39) & $424(39)$ & $169(40)$ \\
\hline & & & $8 \%$ & $-13(31)$ & $17(31)$ & $-42(32)^{d}$ \\
\hline & & 50 & $4 \%$ & 1998(38) & $2636(38)$ & $1360(38)$ \\
\hline & & & $8 \%$ & $382(29)$ & $530(29)$ & $234(30)^{\mathrm{d}}$ \\
\hline & 400 & 10 & $4 \%$ & $-78(44)$ & $46(43)$ & $-200(46)$ \\
\hline & & & $8 \%$ & $-338(36)$ & $-311(34)$ & $-365(38)$ \\
\hline & & 50 & $4 \%$ & $1610(39)$ & $2248(39)$ & $938(40)$ \\
\hline & & & $8 \%$ & $47(31)$ & $195(30)$ & $-100(31)^{\mathrm{d}}$ \\
\hline & 1200 & 10 & $4 \%$ & $-1017(55)$ & $-910(51)$ & $-1113(62)$ \\
\hline & & & $8 \%$ & $-1175(47)$ & $-1156(43)$ & $-1191(54)$ \\
\hline & & 50 & $4 \%$ & $598(41)$ & $1229(41)$ & $-29(43)$ \\
\hline & & & $8 \%$ & $-830(33)$ & $-687(32)$ & $-970(35)$ \\
\hline
\end{tabular}

${ }^{a}$ Optimal rotation ages are in parentheses.

${ }^{\mathrm{b}}$ Harvest age adjusted to 53 years for black spruce, the age at which at least $80 \mathrm{~m}^{3} / \mathrm{ha}$ is available for harvest; see text for details.

${ }^{c}$ Harvest age adjusted to 47 years for black spruce, the age at which at least $80 \mathrm{~m}^{3} /$ ha is available for harvest.

${ }^{\mathrm{d}}$ Harvest age adjusted to 64 years for black spruce and 34 years for white pine, the age at which at least $80 \mathrm{~m}^{3} / \mathrm{ha}$ is available for harvest.

as an important policy goal. Indeed, NPV values can change quite dramatically from positive to negative as the discount rate and establishment costs increase.

The cost of replanting has a larger relative impact on rotation length than changes in the stumpage price. Increasing the cost of establishing a forest stand, which is incurred at the beginning of a cycle, lengthens the optimal rotation period and decreases returns. For example, increasing the establishment cost for white pine from $\$ 100 /$ ha to $\$ 1200 /$ ha for a stumpage price of $\$ 50 / \mathrm{m}^{3}$ and a discount rate of $4 \%$ increases optimal rotation age by three years (from 38 years to 41 years), but the associated returns fall by around $\$ 1500 / \mathrm{ha}$.

Increasing the discount rate reduces the value of future revenue streams relative to establishment costs, which are borne at the start of the forest stand. As noted, the result is a decrease in the optimal rotation age and a decrease in NPV from an increase in the opportunity cost of funds. For example, given a stumpage price of $\$ 50 / \mathrm{m}^{3}$ and an establishment cost of $\$ 100$ / ha, the optimal rotation age for white pine falls from 38 years with $4 \%$ discount rate to 29 years with $8 \%$ discount rate. The associated NPV for each rotation falls dramatically by $\$ 1998 /$ ha to $\$ 382 /$ ha.

Perceptions/expectations on future stumpage prices are also very influential on NPV results. Undoubtedly, some readers will suggest that stumpage values (i.e., the stumpage price plus any additional economic rent) are influenced by a myriad of factors such as merchantable volumes in the stand and distances to mills and could also vary through time and in relation to stand age. This is a complicated subject and, while it is true that stumpage values would vary in relation to such factors, it is usually the stumpage price received that is the revenue to be applied against the silvicultural cost. 
Any excess rent above the stumpage fee would be accrued by the firm harvesting the timber and its benefactors. Losses would be borne by the silviculture investors. A detailed treatise of this subject is beyond the scope of the current paper. The range of stumpage values used in this study should reasonably represent alternative views about future stumpage values.

One final note is that the results in Table 2 are for site class 1 only; results for lower-quality site classes are similar in qualitative terms but the actual numerical results differ.

\section{Climatic change effects on NPV and rotation age}

Results depicting a climatic change manifested by $30 \%$ increase and decrease in volume growth are also listed in Table 1. The optimal rotation age under the Faustmann rule changes slightly with climate change. For example, on site class 1 with a stumpage price of $\$ 20 / \mathrm{m}^{3}$, establishment costs of $\$ 300 /$ ha and a discount rate of $4 \%$, a lower growth rate lengthens the optimal harvest age by two years (from 56 years to 58 years) for black spruce and one year (from 40 years to 41 years) for white pine compared to the no climate change case. An increase in volume due to climate change decreases the optimal rotation age marginally. More specifically, the optimal rotation age on site class 1 decreases by one year (from 56 years to 55 years) for black spruce and stays the same (40 years) for white pine. The major changes in rotation age occur when the harvest volume restriction of $80 \mathrm{~m}^{3} /$ ha becomes binding or is relaxed. For example, under the base conditions, the optimal rotation age for black spruce is 56 years under the current climate with the Faustmann rule and increases to 58 years when climate change reduces productivity. However, the resulting volume at 58 years is 70 $\mathrm{m}^{3} /$ ha and the harvest age is delayed until 64 years when volume is 80 $\mathrm{m}^{3} /$ ha. The merchantable volume issue is directly related to the standing timber value question, which we noted above. While having relatively minor impacts on when to harvest, the assumed output changes (both positive and negative) have more significant effects on NPV. The Faustmann rule returns to both species are increased (decreased) by approximately $50 \%$ with the rise (fall) in output.

These climate change assumptions do not affect the rotation age under the MSY criteria. This is due to the manner in which climate change is assumed to affect productivity, a constant percentage change for each age rather than changing the growth rate through time. However, the general result of MSY rotation ages being longer than the Faustmann result continues to hold and is the most important outcome.

The effects of climate change scenarios on NPV for alternative rotation ages on class 1 and 3 sites are illustrated graphically in Fig.1. The peak of the graph, or the maximum NPV point, indicates the optimal (Faustmann) rotation age and is associated with lower ages on higher-quality land for both species. Climate-enhanced productivity shifts the NPV upwards with only a slight shift in the position of the curve (small change in optimal rotation length). The effect on NPV from a productivity change is most pronounced on better-quality land. On site class 1 , the difference of NPV at the optimal rotation length for black spruce is nearly $\$ 140 /$ ha but just 
$\$ 20 /$ ha on site class 3 . The white pine NPV curve shows the same characteristics shown for black spruce but there is a larger difference in NPVs. The relative changes in NPV are more significant: $\$ 500 /$ ha on site class 1 and $\$ 90 /$ ha on site class 3 .

Table 2 reports the results of rotation age and corresponding NPV given different establishment costs and stumpage value assumptions and climate change scenarios. Climate change has little effect on harvest age except under price conditions of a low stumpage value and the more expensive regeneration option. With an establishment cost of $\$ 100 /$ ha and a discount rate of $4 \%$, the rotation age black spruce is altered by just two years (from 54 years, with productivity enhancing climate change to 56 years with climate reducing growth) with a stumpage price of $\$ 10 / \mathrm{m}^{3}$ and just one year (from 51 years to 52 years) with a stumpage price of $\$ 50 /$ $\mathrm{m}^{3}$. The result suggests that climate-induced volume changes may not impact when to harvest but rather affect the net returns. However, an increased investment (establishment costs of $\$ 1200 /$ ha) causes a relatively large increase in the harvest period by 24 years (from 79 years to 103 years) with the stumpage price of $\$ 10 / \mathrm{m}^{3}$ and discount rate of $4 \%$. Under similar price conditions, the optimal rotation age for white pine is delayed by 11 years (from 51 years to 62 years) with negative climate change.

\section{Concluding Comments}

We have provided a depiction of the differences between biophysically and economically oriented sustained yield rules (MSY vs. Faustmann). The biological rule is aimed at maximizing wood production per se, whereas the economic rule is targeted more towards maximizing the value of the standing timber. The two harvest criteria result in clear and substantial financial, biophysical (wood volume) and harvest age trade-offs. Following the Faustmann rule results in less harvest volume due to an earlier cut but provides higher expected economic returns to silvicultural investments. The MSY criterion ignores the opportunity cost of silvicultural investments and the value of the standing timber (Samuelson 1976, Newman 1988). Depending on how climate change effects on stand growth are depicted, the Faustmann approach could shorten or lengthen the economically efficient rotation period. The effect of a changing climate on forest growth remains the subject of considerable research but at this stage it would seem prudent for forest planners to more closely examine the implications of different climate paths on growth and yield.

Among the four factors examined here (i.e., real stumpage value, silviculture/investment cost, discount rate and growth rate changes due to climate), the discount rate has the largest effect on rotation age. For example, a rise in the interest rate from $4 \%$ to $8 \%$ reduces the rotation age by around nine years for white pine for any set of prices and climate scenarios. In contrast, the larger proportional change in stumpage price (from $\$ 10 / \mathrm{m}^{3}$ to $\$ 50 / \mathrm{m}^{3}$ ) with an establishment cost less than $\$ 400 /$ ha reduces the rotation age by a maximum of around five years. Harvest age increases by a maximum of nearly five years if establishment costs are increased from $\$ 100 /$ ha to $\$ 400 /$ ha. Similarly, the difference in rotation age between the climate change scenarios is a maximum of four years for white pine. Although growth rate changes had less of an impact on rotation age than the discount rate, there are situations where the change in volume can alter the timing of the harvest decision. If the restriction on the harvest volume is relaxed (binding) due to productivity enhancing (reducing) climate change, the optimal rotation age also could be significantly shortened (lengthened). However, it is noteworthy that these differences in rotation ages are minuscule in comparison to the differences between MSY and Faustmann ages more generally.

Although these results suggest climate change may only slightly alter the harvest length, this analysis does not account for the possibility of greater fire risk associated with a warming climate (Gillett et al. 2004, Boulanger et al. 2013). Martell (1980), Reed (1984) and Reed and Errico (1985) found that the presence of a stochastic fire event shortens the period of rotation compared to the scenario with no fire risk. However, these studies did not formally estimate fire occurrence under climate change per se. Boulanger et al. (2013, 2014) predict that the annual area burned and number of fires could increase by 2.2- to 2.4-fold in boreal Canada in the near future. More specifically, the annual fire probability is estimated to increase two- to fourfold in more southern and eastern regions of Ontario and more than fourfold in northeastern and central Ontario so that the annual fire risk will be around 0.5\% (Boulanger et al. 2013, 2014). According to Martell (1980), this increase in the probability of fire reduces optimal harvest ages by at least one year.

Beyond timber products and non-wood values such as wildlife habitat and recreation opportunities, forests can also be used to sequester atmospheric carbon and therefore may help mitigate the effects of climate change (Sedjo et al. 1995, Richards and Stokes 2004). Thus, carbon sequestration is becoming an increasingly important and recognized value of forest management (e.g., Englin and Callaway 1993, Gutrich and Howarth 2007, Erhun and Yavuz 2012, Lemprière et al. 2013, Hoel et al. 2014). If the benefits of carbon sequestration were monetized through a carbon price, the optimal rotation length would increase. However, this result may not hold in the face of fire risk (Stainback and Alavalapati 2004, Stollery 2005, Couture and Reynaud 2011).

The forest management problem is complicated with many interacting costs and benefits. Our exploration of some of the trade-offs was intended to be illustrative rather than prescriptive. Future work could and should more carefully examine issues such as a stumpage valuation, growth and yield changes in an evolving climate, changes in fire and insect disturbance regimes due to a changing climate, non-wood values and other sustainable forest management concerns. Blanket application of simple rules of thumb like MSY seems both inappropriate and unnecessary given today's technology and data availability and concerns about economic efficiency. Frameworks like the Faustmann model (if applied and interpreted appropriately) should be more widely used to help improve forest management planning, indeed perhaps more so now given the context of an evolving and uncertain climate. 


\section{References}

Aitken, S.N., S. Yeaman, J.A. Holliday, T. Wang and S. CurtisMcLane. 2008. Adaptation, migration or extirpation: Climate change outcomes for tree population. Evol. Appl. 1(1): 95-111.

Binkley, C.S. 1987. When is the optimal economic rotation age longer than the rotation age of maximum sustained yield? J. Environ. Econ. Manage. 14(2): 152-158.

Boardman, A.E., M.A. Moore and A.R. Vining. 2010. The social discount rate for Canada based on future growth in consumption. $\mathrm{Ca}-$ nadian Public Policy 36(3): 325-343.

Boulanger, Y., S. Gauthier and P.J. Burton. 2014. A refinement of models projecting future Canadian fire regimes using homogeneous fire regime zones. Can. J. For. Res. 44(4): 365-376.

Boulanger, Y., S. Gauthier, D.R. Gary, H.L. Goef, P. Lefort and J. Morissette. 2013. Fire regime zonation under current and future climate over eastern Canada. Ecol. Appl. 23(4): 904-923.

Bowes, M.D. and J.V. Krutilla. 1989. Multiple-use management: the economics of public forestlands. Resources for the Future, Washington, DC.

Campbell, J. L. et al. 2009. Consequences of climate change for biogeochemical cycling in forests of Northeastern North America. Can. J. For. Res. 39(2): 264-284.

Chang, S.J. 1984. Determination of the optimal rotation age: a theoretical analysis. For. Ecol. Manage. 8(2): 137-147.

Conrad, J.M. 1999. Resource Economics. Cambridge University Press.

Coulombe, S., P.Y. Bernier and F. Raulier. 2010. Uncertainty in detecting climate change impact on the projected yield of black spruce (Picea mariana). For. Ecol. Manage. 259 (4): 730-738.

Couture, S. and A. Reynaud. 2011. Forest management under fire risk when forest carbon sequestration has value. Ecol. Econ. 70(11): 2002-2011.

Englin, J. and J.M. Callaway. 1993. Global climate change and optimal forest management. Nat. Resour. Model. 7(3): 191-202.

Erhun, K. and G. Yavuz. 2012. Carbon sequestration, optimum forest rotation and their environmental impact. Environ. Impact Assess. Rev. 37 (1):18-22.

Faustmann, M. 1849. On the determination of the value which forest land and immature stands possess for forestry. English edition. In M. Gane (ed.). 1968. Martin Faustmann and the Evolution of Discounted Cash Flow. Institute Paper 42. Commonwealth Forestry Institute, Oxford University Press.

Gillett, N.P., A.J. Weaver, F.W. Zwiers and M.D. Flannigan. 2004. Detecting the effect of climate change on Canadian Forest fires. Geophys. Res. Lett. 31: L18211.

Girardin, M.P., F. Raulier, P.Y. Bernier and J.C. Tardif. 2008. Response of tree growth to a changing climate in boreal central Canada: a comparison of empirical, process-based, and hybrid modeling approach. Ecol. Modell. 213 (2): 209-228.

Gutrich, J. and R. Howarth. 2007. Carbon sequestrations and the optimal management of New Hampshire timber stands. Ecol. Econ. 62(3): 441-450.

Hartman, R. 1976. The harvesting decision when a standing forest has value. Economic Enquiry 14(1): 52-58.

Hoel, M., B. Holtsmark and K. Holtsmark. 2014. Faustmann and the climate. J. For. Econ. 20(1): 192-210.

Insley, M., G. Fox, and K. Rollings. 2002. The economics of intensive forest management: A stand level analysis for the Romeo Malette forest in Ontario. A Report Prepared for Tembec Inc., the Ontario Ministry of Natural Resources, and ULERN.
[IPCC] Intergovernmental Panel on Climate Change. 2007. Climate Change 2007: The Physical Science Basis. In Contribution of Working Group I to the Fourth Assessment Report of the Intergovernmental Panel on Climate Change. Cambridge University Press, Cambridge, UK; New York, NY.

. 2013. Climate Change 2013: The Physical Science Basis. In Working Group I Contribution to the Fifth Assessment Report of the Intergovernmental Panel On Climate Change. Cambridge University Press, Cambridge, UK; New York, NY.

Johansson, P. and K. Lofgren. 1985. The Economics of Forestry and Natural Resources. Basil Blackwell, Oxford, UK.

Kula, E. 1984. Derivation of social time preference rates for the United States and Canada. Q. J. Econ. 99(1): 873-878.

Lemprière, T.C. et al. 2013. Canadian boreal forests and climate change mitigation. Environ. Rev. 21(4): 293-321.

Luckert, M.K. 2002. Inquiries into the role of economics in Canadian forestry. For. Chron. 78(4): 499-504.

Luckert, M.K. and T. Williamson. 2005. Should sustained yield be part of sustainable forest management? Can. J. For. Res. 35(2): 356-364.

Martell, D.L. 1980. The optimal rotation of a flammable forest stand. Can. J. For. Res. 10(1): 30-34.

McKenney, D.W. 2000. What's the economics of intensive silviculture? For. Chron. 76(2): 275-281

McKenney, D.W., J. H. Pedlar, K. Lawrence, K. Campbell and M. Hutchinson. 2007. Potential impacts of climate change on the distribution of North American Trees. Biosci. 57(11): 939-948.

McKenney, D.W., J.H. Pedlar and G.A. O’Neill. 2009. Climate change and forest seed zones: past trends, future prospects and challenges to ponder. For. Chron. 85(2): 258-266.

McKenney, D.W., J.H. Pedlar, R.B. Rood and D. Price. 2011a. Revisiting projected shifts in the climate envelopes of North American trees using updated general circulation models. Global Change Biol. 17(8): 2720-2730.

Moore, M.A., A.E. Boardman and A.R. Vining. 2013. More appropriate discounting: the rate of social time preference and the value of the social discount rate. J. Benefit-Cost Anal. 4(1): 1-16.

Newman, D.H. 1988. The optimal forest rotation: A discussion and annotated bibliography. U.S. Department of Agriculture, Forest Service, Southeastern Forest Experiment Station, Asheville, NC. General Technical Report SE-48.

Newman, D.H. 2002. Forestry's golden rule and the development of the optimal forest rotation literature. J. For. Econ. 8(1): 5-27.

Nguyen, D. 1979. Environmental services and the optimum rotation problem in forest management. J. Environ. Manage. (2): 127-136.

[OMNR] Ontario Ministry of Natural Resources. 2014. Valuing Nature: A policy lens. Strategic Policy and Economics Branch, Policy Division.

Park, A., K. Puettmann, E. Wilson, C. Messier, S. Kames and A. Dhar. 2014. Can Boreal and Temperate Forest Management be Adapted to the Uncertainties of 21st Century Climate Change? Crit. Rev. Plant Sci. 33(4), 251-285.

Payandeh, B. 1991. Plonski's (metric) yield tables formulated. For. Chron. 67(5): 545-546.

Pearse, P.H. 1967. The optimum forest rotation. For. Chron. 43(2): 178-195.

Pedlar J.H., McKenney D.W., Aubin I., Beardmore T., Beaulieu J., Iverson L., O'Neill G.A., Winder R.S., and Ste-Marie C. 2012. Placing forestry in the assisted migration debate. BioScience 62:835-842. 
Plonski, W.L. 1956. Normal yield tables for black spruce, jack pine, aspen, and white birch in northern Ontario. Ontario Department of Lands and Forests Timber Branch. Report No. 24.

Plonski, W.L. 1960. Normal yield tables for Black Spruce, Jack Pine, Aspen, White Birch, tolerant hardwoods, White Pine, and Red Pine for Ontario. Silvicultural Series Bulletin, Ontario Department of Lands and Forests 2.

Portney, P.R. and J.P. Weyant. 1999. Discounting and Intergenerational Equity. Resources for the Future, Washington, DC.

Price, D.T. et al. 2013. Anticipating the consequences of climate change for Canada's boreal forest ecosystem. Environ. Rev. 21(4): 322-365.

Reed, W.J. 1984. The Effects of the Risk of Fire on the Optimal Rotation of a Forest. J. Environ. Econ. And Mange. 1(1): 180-190.

Reed, W.J. and D. Errico. 1985. Assessing the long-run yield of a forest stand subject to the risk of fire. Can. J. For. Res. 15 (4): 680-687.

Richards, K.R. and C. Stokes. 2004. A review of forest carbon sequestration cost studies: A dozen years of research. Climatic Change 63(1): $1-48$.

Rollins, R., M. Forsyth. S. Bonti-Ankomah and B. Amoah. 1995. A financial analysis of a white pine improvement cut in Ontario. For. Chron. 71(4): 466-472.

Row, C., H.F. Kaiser and J. Sessions. 1981. Discount rate for longterm forest service investment. J. For. 79(6): 367-369.

Samuelson, P.A. 1976. Economics of forestry in an evolving society. Econ. Inq. 14(4): 466-492.
Sedjo, R.A., J. Wisniewski, A.V. Sample and J.D. Kinsman. 1995. The economics of managing carbon via forestry: assessment of economic studies. Environ. Resour. Econ. 6 (2): 139-165.

Seidl, R., W. Rammer and M.J. Lexer. 2011. Adaptation options to reduce climate change vulnerability of sustainable forest management in the Austrian Alps. Can. J. For. Res. 41(4): 694-706.

Sharma, M., W.J. Parton, M. Woods, P.F. Newton, M. Penner, J. Wang, A. Stinson and F.W. Bell. 2008. Ontario's forest growth and yield modeling program: Advances resulting from the Forestry Research Partnership. For. Chron. 84(5): 694-703.

Stainback, G.A. and J.R.R. Alavalapati. 2004. Modeling catastrophic risk in economic analysis of forest carbon sequestration. Nat. Resour. Model. 17(3): 299-317.

Stollery, K. 2005. Climate change and optimal rotation in a flammable forest. Nat. Resour. Model. 18(1): 91-112.

Ung, C.H., P.Y. Bernier, X.J. Guo and M.C. Lambert. 2009. A simple growth and yield model for assessing changes in standing volume across Canadàs forests. For. Chron. 85(1): 57-64.

Walker, J.L. 1990. Traditional sustained yield management: problems and alternatives. For. Chron. 66 (1): 20-24.

Williams, M.I. and R.K. Dumroese. 2013. Preparing for climate change: forestry and assisted migration. J. For. 111(4): 287-297. 